\title{
Prevalence of Intestinal Parasitic Infestation Among Expatriate Workers
}

Azhar Hussain 1, 2 , Eman Z. Younis ${ }^{3,4}$, Adela H. Elamami ${ }^{5}$, Mehrdad Jelodar ${ }^{6}$, Tulika Mishra ${ }^{7}$, Gopikumar Shivaramaiah 8

1. Healthcare Administration, Franklin University, Columbus, USA 2. Medicine, Xavier University School of Medicine, Oranjestad, ABW 3. Laboratory Medicine, University of Benghazi, Benghazi, LBY 4. Biology, University of Benghazi, Benghazi, LBY 5. Internal Medicine, University of Benghazi, Benghazi, LBY 6. Internal Medicine, Xavier University School of Medicine, Oranjestad, ABW 7. Health Biotech, Immunology, Microbiology, Xavier University School of Medicine, Oranjestad, ABW 8. Physiology, Xavier University School of Medicine, Oranjestad, ABW

Corresponding author: Azhar Hussain, azharhu786@gmail.com

\section{Abstract}

\section{Background}

Parasitic infestations of the gastrointestinal tract remain a common problem in third-world countries. Poverty, illiteracy, poor hygiene, scarcity of potable water, as well as the hot and humid tropical climate, are all contributing factors associated with intestinal parasitic infestation.

\section{Objective}

This cross-sectional study aims to evaluate the prevalence of intestinal parasitic infestation amongst expatriate workers in Benghazi City, Libya.

\section{Patients and methods}

A total of 250 stool samples (200 male and 50 female) were randomly collected between October 2017 to April 2018 from expatriate workers in Benghazi City, Libya. The samples examined were used to detect the presence of intestinal parasitic infestation while the study utilized a pre-tested structure. Cases were matched based on demographic parameters, such as age, gender, and nationality, while the history of diarrhea was recorded using direct smear microscopy for the detection of intestinal parasitic infestation.

\section{Results}

Received 05/29/2019 Review began 06/08/2019 Review ended 06/12/2019 Published 06/13/2019

\section{(c) Copyright 2019}

Hussain et al. This is an open access article distributed under the terms of the Creative Commons Attribution License CC-BY 3.0., which permits unrestricted use, distribution, and reproduction in any medium, provided the original author and source are credited.
Of the 250 immigrants looking for work, 95 (38\%) were found to be infested with two or more intestinal parasites. The protozoa included: Blastocystis hominis, Giardia lamblia, Entamoeba histolytica, Entamoeba dispar, and Cryptosporidium parvum (47.4\%, 38.9\%, 17.9\%, 17.9\%, and $4.2 \%$, respectively); the non-pathogenic protozoa included the prevalence of Entamoeba coli (E. coli), which is $12.6 \%$, and the helminth Ascaris lumbricoides is $1.1 \%$.

\section{Conclusion}

The prevalence of parasitic infection was relatively high (38\%) and was affected by individual hygiene. Therefore, comprehensive healthcare education aimed at reducing parasitic infestation is needed. 
Categories: Internal Medicine, Infectious Disease, Epidemiology/Public Health

Keywords: expatriate workers, intestinal parasites, cryptosporidium parvum, blastocystis hominis, giardia lamblia, entamoeba histolytica, entamoeba dispar

\section{Introduction}

Intestinal parasitic infestations are distributed throughout the world, with a high prevalence in the poor and socio-economically depressed communities in the tropics and subtropics. These infestations have a clear association with human malnutrition [1], and it is a serious public health threat globally [2]. The high frequency of intestinal parasites in the population of a region indicates low socio-economic developmental conditions, poor medical care, occupational exposure, and a low standard of hygiene [3-4]. Parasitic infections, particularly intestinal helminths, cause hundreds of thousands of avoidable deaths each year and are among the world's common infectious diseases. Intestinal helminths are more prevalent throughout the tropics, especially among poor communities. Records show increasing trends in helminthiasis, particularly in developing nations [5]. This is a public health problem with an estimated 3.5 billion people being infected worldwide, as the majority affected are children [67]. Socio-economic factors, such as poor hygiene, shortage of safe water supply and sanitation facilities, and low socioeconomic status, are known to play a pivotal role in susceptibility to infection [8].

\section{Aim of the study}

This study was conducted to determine the prevalence of intestinal parasites and to identify the factors that contribute to the spread of intestinal parasites among expatriate workers in Benghazi, Libya.

\section{Materials And Methods}

\section{Study area}

Located in North Africa, along the Mediterranean Sea, Benghazi is the second largest city in Libya. It is seen neighboring Egypt, Sudan, Chad, Niger, Algeria, and Tunisia.

\section{Study design and patients}

A cross-sectional study was conducted in Benghazi city. The study included 250 stool samples (200 male and 50 female), including samples from the Anti-Illegal Immigration Agency of the Ministry of the Interior, during the period from October 2017 to April 2018. Cases were matched according to demographic parameters such as age, gender, and nationality. A history of diarrhea was recorded.

\section{Collection of samples}

A single stool sample of about 2-5 grams was obtained from each individual for the expected parasites; each sample was collected fresh in a sterile plastic vial, then properly identified, and immediately transferred to the medical laboratory department of the Institute of Benghazi. The stool samples were assessed by direct smear ( $\pm 2 \mathrm{mg}$ of feces) in physiologic saline solution, direct smear in Lugol's iodine solution, formaldehyde-ether sedimentation method, and by the modified acid-fast stain in order to identify oocysts of opportunistic coccidian intestinal parasite [9]. All the samples were then placed in $10 \%$ formalin as a fixative, and a questionnaire was distributed to the expatriate workers. The questionnaire was prepared to collect the sociodemographic and clinical data from each participant, including age, gender, and nationality. 


\section{Cureus}

\section{Statistical analysis}

Data entry and data analysis were done using Statistical Package for Social Science (SPSS), software version 17 (IBM Corp, Armonk, NY, US). A descriptive analysis was performed for demographic findings and categorical variables. The $\chi 2$-test was employed to find the significance or non-significance of the relationships between age, sex, and symptoms and the presence or absence of parasites. The accepted level of significance $\mathrm{P}<0.05$ was considered significant [10].

\section{Results}

As illustrated in Figure 1 and Table 1, the overall prevalence of infestation with intestinal parasites among various populations was 38\% (95/250) of the patient population.

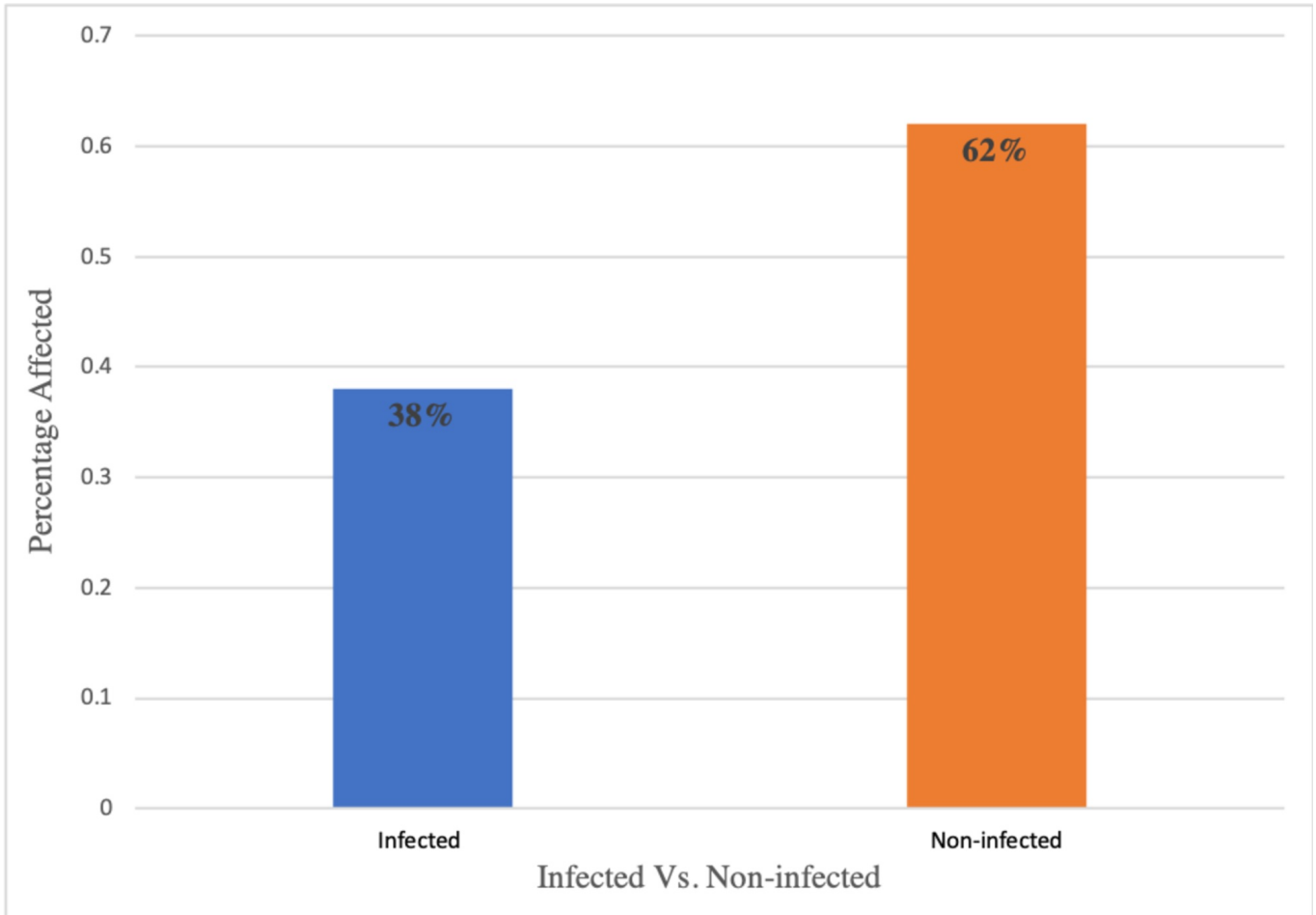

FIGURE 1: Percentage distribution of parasitic infestations amongst various populations

Number examined

250
Infected

95
Non-infected

155

\section{TABLE 1: Overall distribution of intestinal parasitic infestations amongst various populations}




\section{Cureus}

differences between age group and infestation ( $\mathrm{P}>581)$. Our results, as shown in Table 2 and Figure 2, revealed that the prevalence rate of infestation was higher in males (85/200 (42.5\%)) as compared to females 10/50 (20\%) in expatriate workers.

\begin{tabular}{|c|c|c|c|c|c|c|}
\hline \multirow{2}{*}{ Infection } & \multicolumn{5}{|l|}{ Age } & \multirow{2}{*}{ Total } \\
\hline & $14-24$ & $25-35$ & $36-46$ & $47-57$ & 58 or older & \\
\hline Positive count $\%$ within parasitic infestation & 53 & 21 & 18 & 1 & 2 & 95 \\
\hline Number examined & 137 & 65 & 41 & 4 & 3 & 250 \\
\hline
\end{tabular}

TABLE 2: Distribution of intestinal parasites according to age group amongst various populations

$p=0.581$

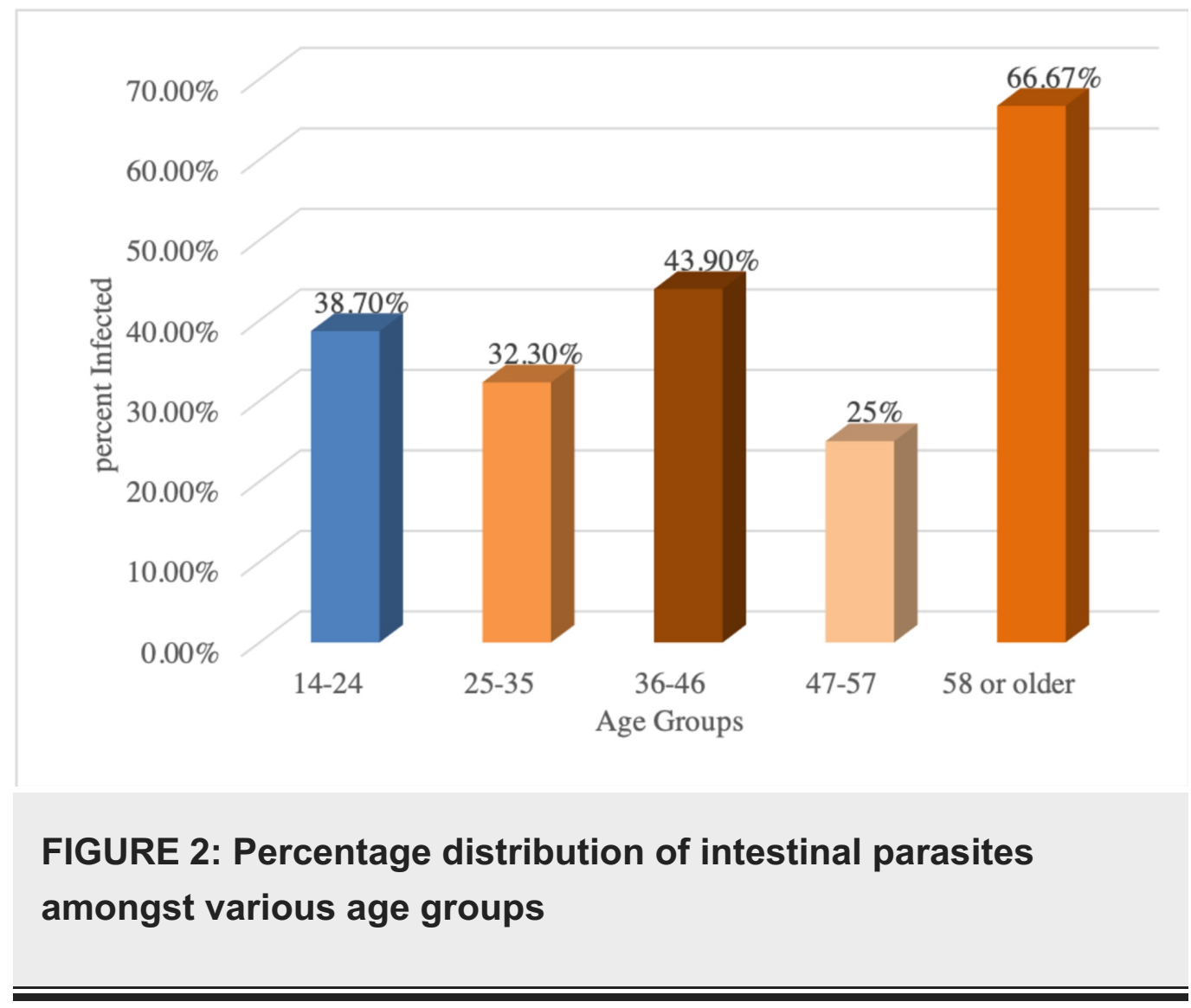

A significant difference $(\mathrm{P}=0.000)$ was found between males and females. The relationship between the prevalence of intestinal parasitic infestation in expatriate workers and sex are presented in Table 3 and Figure 3. 


\section{Cureus}

\begin{tabular}{|l|l|l|}
\hline Gender & Female & Male \\
\hline Infested & 10 & 85 \\
Non-infested & 40 & 115 \\
Total & 50 & 200 \\
\hline
\end{tabular}

TABLE 3: Relationship between the prevalence of intestinal parasitic infestation and sex among expatriate workers

P-value $=0.000$

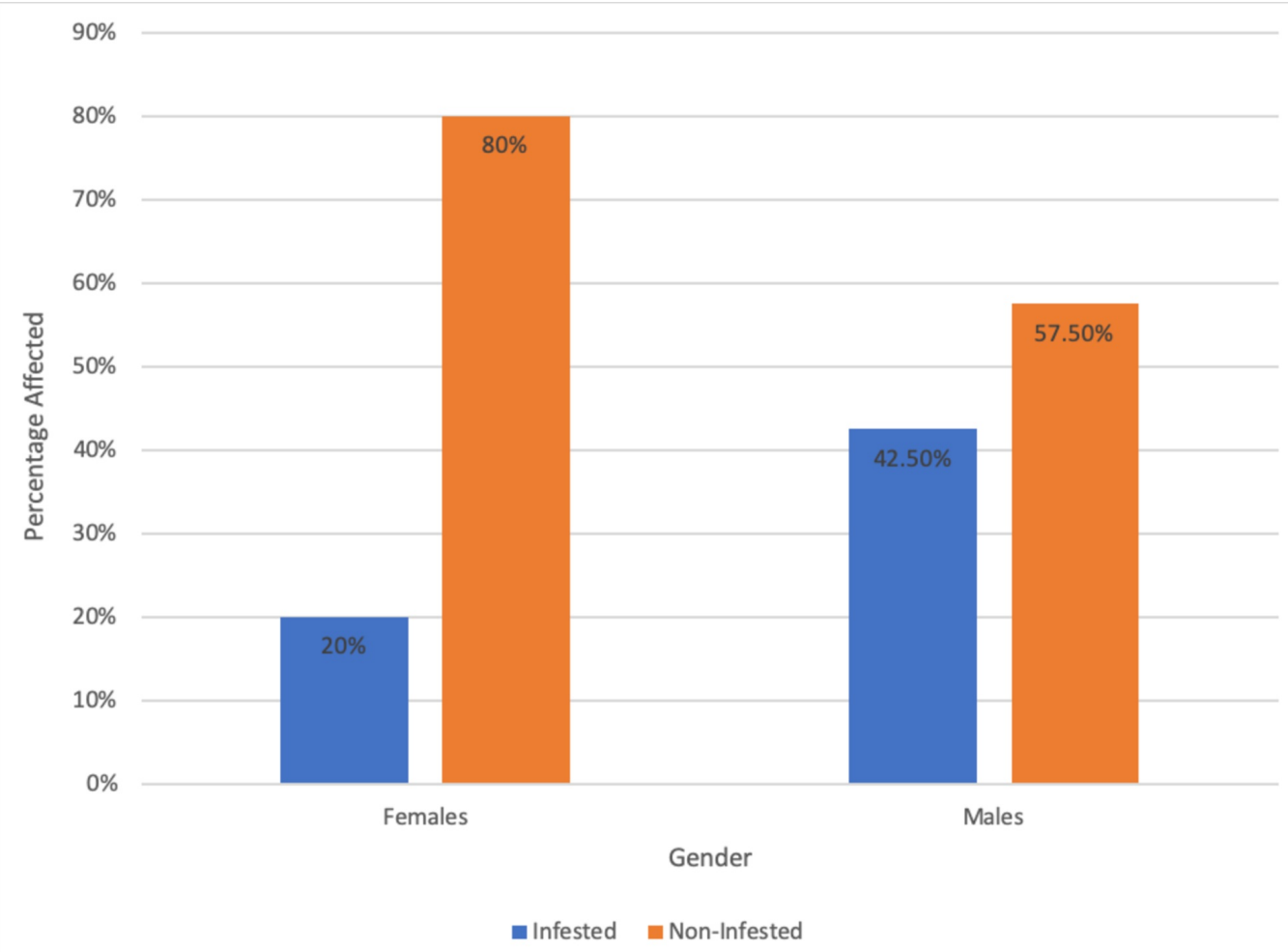

FIGURE 3: Percentage showing the relationship between the prevalence of intestinal infestation and sex amongst expatriate workers

Our study also included the assessment of infested people belonging to various regions. As depicted in Table 4 and Figure 4, the highest prevalence of intestinal parasites was recorded in people with Somalian nationality (66.7\%), followed by Tunisian and Egyptian nationalities (50\%) while fewer parasitic infestation presented among Bangladeshi nationalities (0.00\%). 


\section{Cureus}

\begin{tabular}{|c|c|c|c|c|c|c|c|c|c|c|}
\hline Nationality & Eritrean & Chadian & Egyptian & Ethiopian & Bangladeshi & Sudanese & Somali & Tunisian & Algerian & Total \\
\hline Infested & 6 & 17 & 4 & 14 & 0 & 42 & 6 & 4 & 2 & 95 \\
\hline $\begin{array}{l}\text { Total number per } \\
\text { Nationality }\end{array}$ & 14 & 41 & 8 & 52 & 1 & 111 & 9 & 8 & 6 & 250 \\
\hline
\end{tabular}

\section{TABLE 4: Distribution of parasites according to nationalities}

P-value $=0.449$

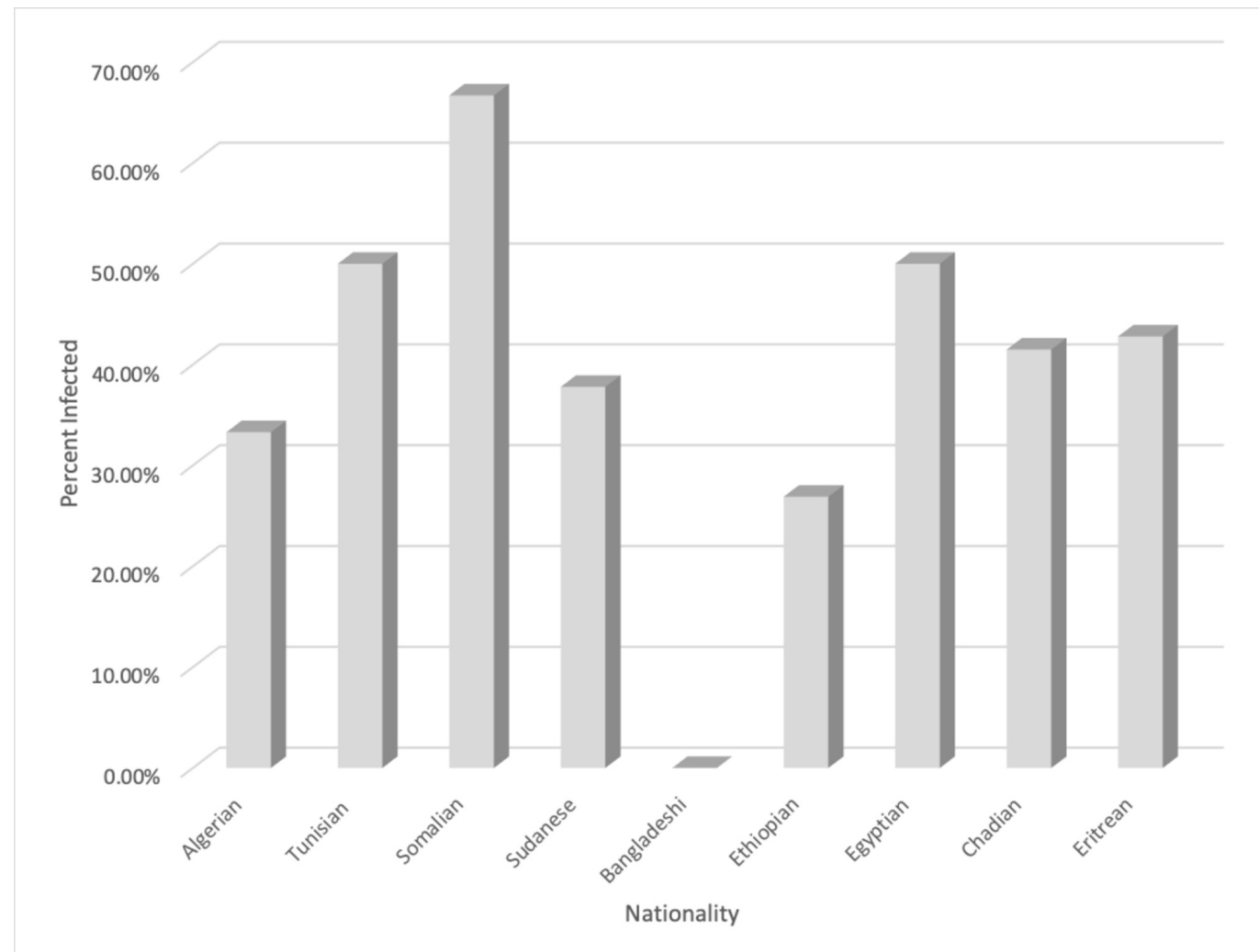

FIGURE 4: Comparative percentage prevalence of intestinal infestation amongst people belonging to different nationalities

There are no significant differences between nationality and parasitic transmissibility $(\mathrm{P}>0.449)$. It was also observed, as shown in Table 5 and Figure 5 , that of all the tested samples, the most common intestinal protozoan parasite was Blastocystis hominis (B. hominis) with the highest prevalence at 47.4\% (45), followed by Giardia lamblia (G. lamblia) at 38.9\% (37), Entamoeba histolytica (E. histolytica) and Entamoeba dispar (E. dispar) at 17.9\%(17), Entamoeba coli (E.coli) at $12.6 \%$ (12), and Cryptosporidium parvum (C. parvum) at $4.2 \%$ (4). Only the helminth parasite, Ascaris lumbricoides (A. lumbricoides), was detected at a low prevalence rate of $1.1 \%$ (1). There were significant differences in prevalence among $\mathrm{B}$. hominis $(\mathrm{P}=0.00)$, G. lamblia $(\mathrm{P}=0.00)$, E. histolytica and E. dispar $(\mathrm{P}=0.00)$, C. parvum $(\mathrm{P}=0.036)$, E. coli $(\mathrm{P}=0.00)$, and no significant differences among A. lumbricoides $(\mathrm{P}=0.201)$, as seen in Table 5 and Figure 5. 


\section{Cureus}

\begin{tabular}{|c|c|c|c|}
\hline \multirow{2}{*}{ Type of parasite } & \multicolumn{2}{|c|}{ Infected ( $n=95)$} & \multirow{2}{*}{ p-value } \\
\hline & Number & $(\%)$ & \\
\hline Blastocystis hominis & 45 & 47.4 & 0.000 \\
\hline Entamoeba histolytica/ Entamoeba dispar & 17 & 17.9 & 0.000 \\
\hline Giardia lamblia & 37 & 38.9 & 0.000 \\
\hline Entamoeba coli & 12 & 12.6 & 0.000 \\
\hline Ascaris lumbricoides & 1 & 1.1 & 0.201 \\
\hline Cryptosporidium parvum & 4 & 4.2 & 0.036 \\
\hline
\end{tabular}

TABLE 5: Prevalence of intestinal parasitic infestations amongst examined patients

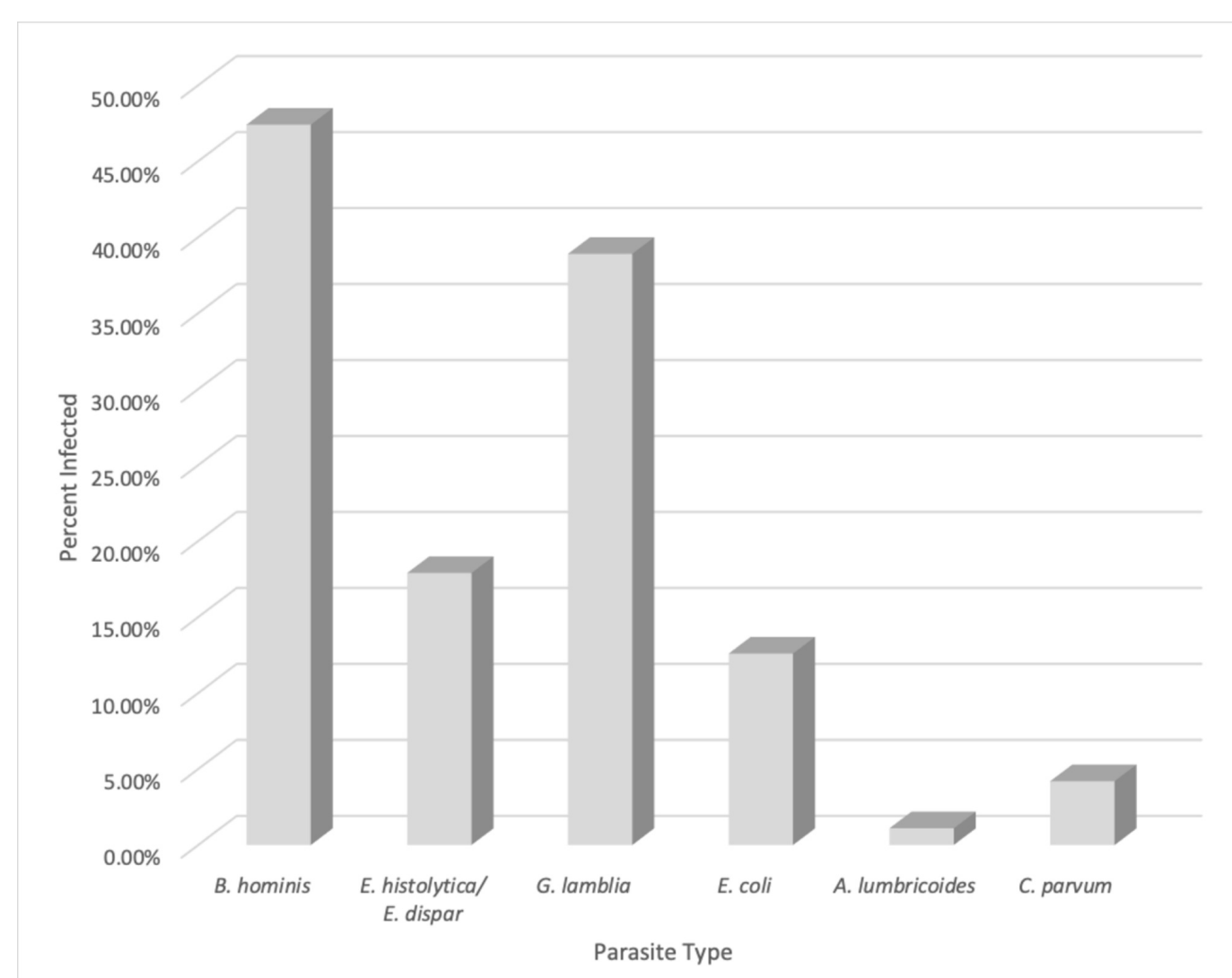

FIGURE 5: Comparative percentage assessment between various agents

Our data, as shown in Table 6 and Figure 6,71.6\% showed infestation by a single parasite.

Twenty-two point one percent (22.1\%) of expatriate workers were found to be infested by two 


\section{Cureus}

species of parasites and only $6 \%$ of the workers showed infestation by three species of parasites. The results showed that there was a high significant difference between prevalence and types of parasitic infestation $(\mathrm{P}=0.000)$. We also attempted to find out the relationship between the prevalence of parasitic infestation and diarrhea.

\section{PATTERN OF INFECTION}

Double infection

Triple infection

Total

\section{INFECTED}

NUMBER

68

71.6

21

6

6.3

95

\section{TABLE 6: Pattern of intestinal parasitic infection among the studied sample}

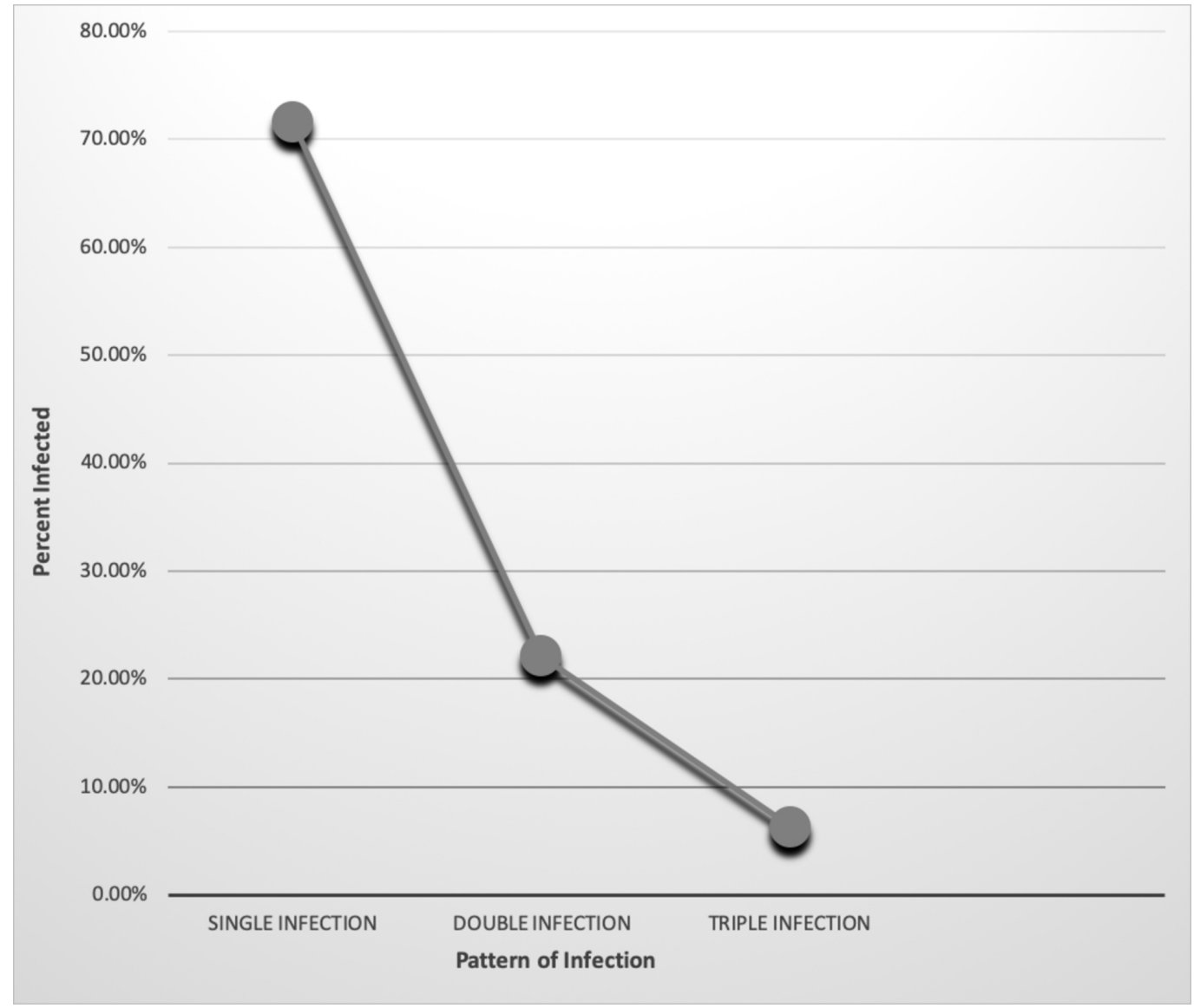

FIGURE 6: Percentage analysis of pattern of infection and prevalence

It was observed that the prevalence of diarrhea with an infestation (83.9\%) was greater than 


\section{Cureus}

that of without diarrhea (31.5\%), as seen in Table 7 and Figure 7 . There was a highly significant difference, which was detected between the prevalence of parasitic infestation and diarrhea $(\mathrm{P}=0.000)$. Data were also analyzed based on the occupation.

\begin{tabular}{|l|l|l}
\hline Diarrhea & Total examined $(\mathbf{n}=\mathbf{2 5 0})$ & With parasitic infection $\mathbf{( n = 9 5 )}$ \\
\hline With diarrhea & 31 & $26(83.9 \%)$ \\
Without diarrhea & 219 & $69(31.5 \%)$ \\
Total & 250 & 95
\end{tabular}

\section{TABLE 7: Relationship between the intestinal parasitic infection and diarrhea} amongst various populations

P-value $=0.000$

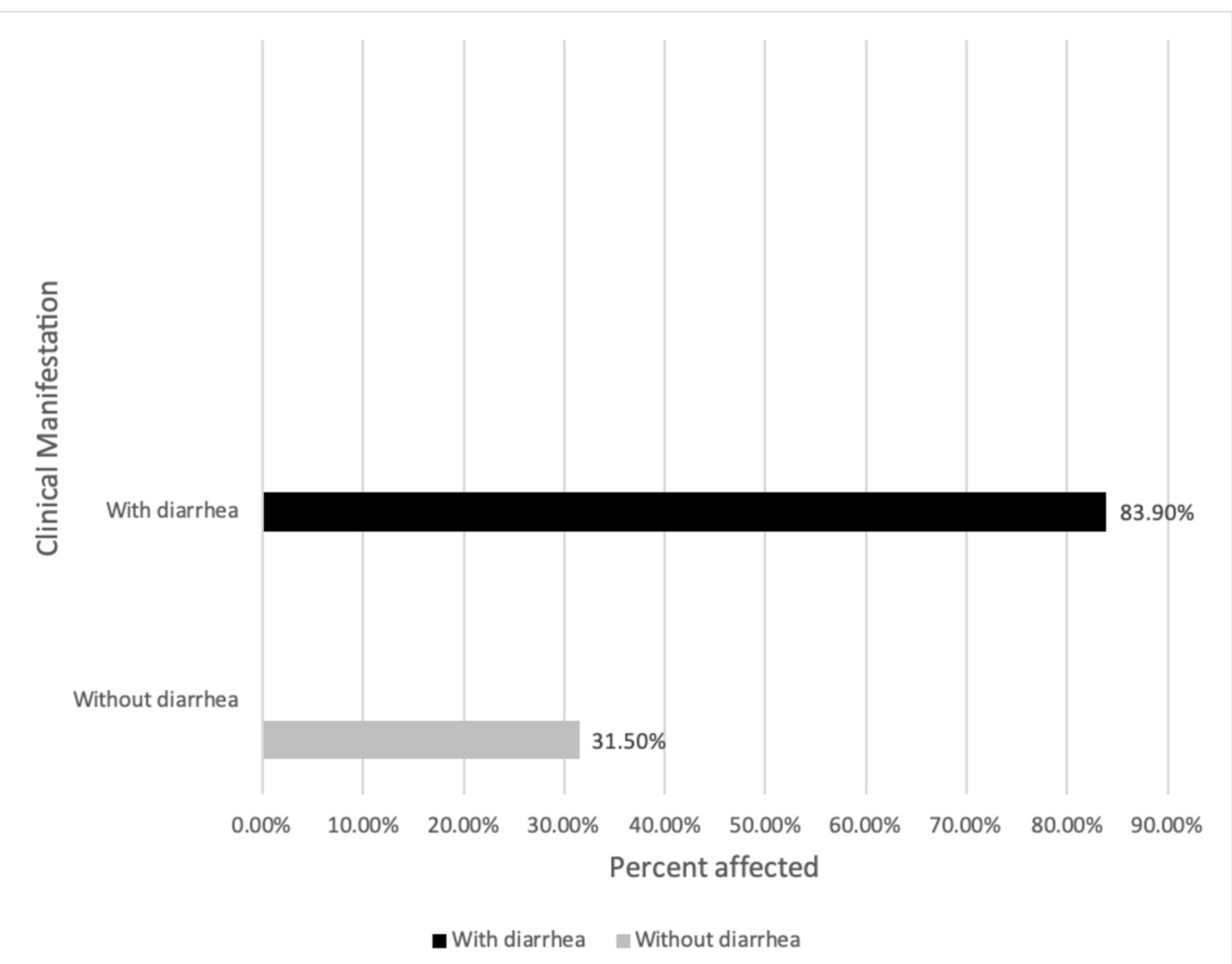

FIGURE 7: Percentage prevalence of intestinal parasitic infestation with and without diarrhea

As depicted in Figure 8 and Table 8 , our results revealed that drivers and security officers showed a $100 \%$ prevalence of infestation while traders, farmers, artisan, unemployed, cleaners, and students showed $80 \%, 66.7 \%, 44 \%, 33.7 \%, 14.3 \%$, and $0.00 \%$, respectively. There was a significant difference between occupation and parasitic infestation ( $p>0.049)$. 


\section{Cureus}

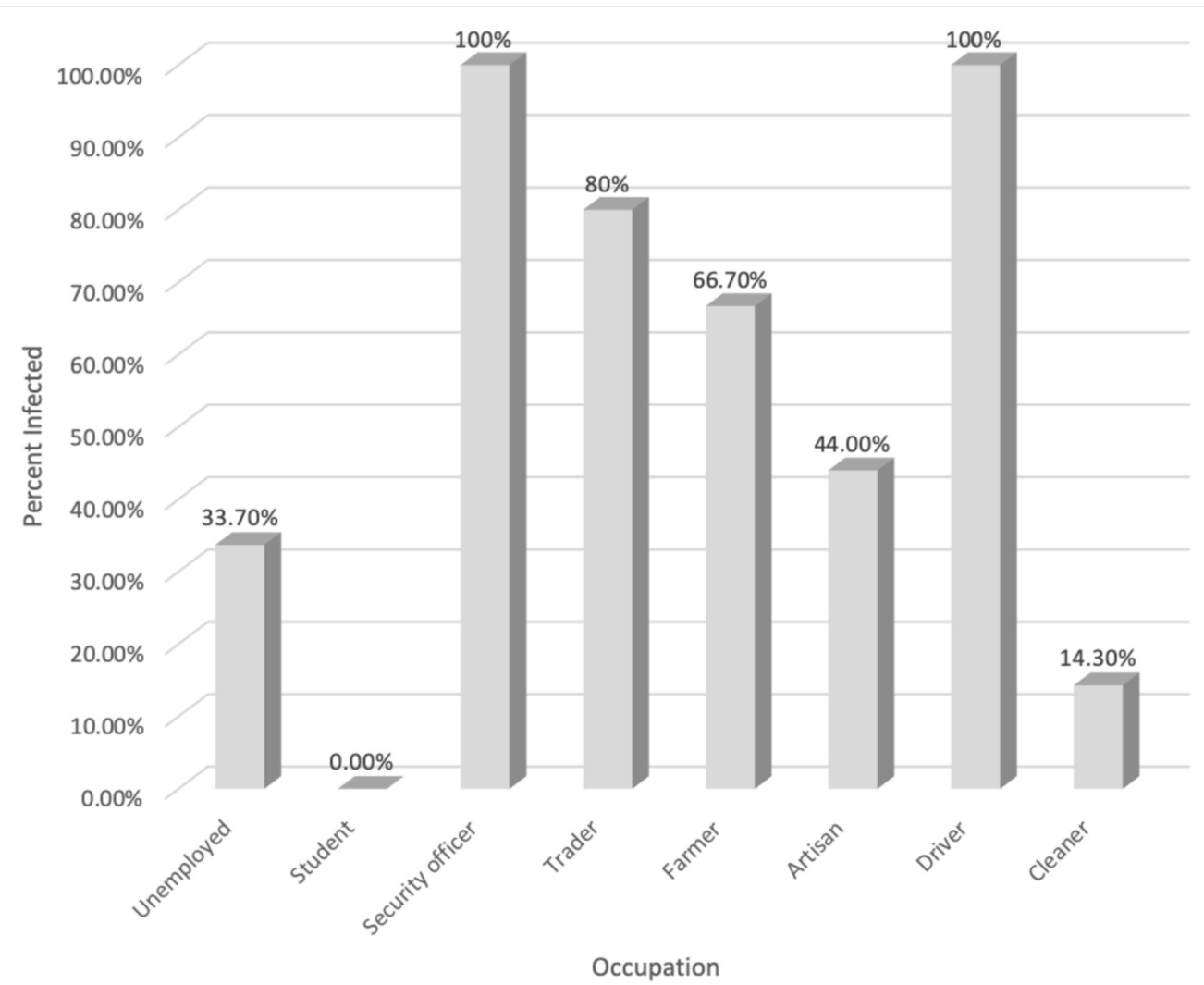

FIGURE 8: Percentile analysis of intestinal parasitic infestation within various occupations

\begin{tabular}{|c|c|c|c|c|c|c|c|c|c|}
\hline Occupation & Unemployed & Student & $\begin{array}{l}\text { Security } \\
\text { officer }\end{array}$ & Trader & Farmer & Artisan & Driver & Cleaner & Total \\
\hline Infested & 64 & 0 & 2 & 4 & 12 & 11 & 1 & 1 & 95 \\
\hline $\begin{array}{l}\text { Total number for each } \\
\text { occupation }\end{array}$ & 190 & 2 & 2 & 5 & 18 & 25 & 1 & 7 & 250 \\
\hline
\end{tabular}

TABLE 8: Relationship between the intestinal parasitic infestation and occupation amongst various populations

P-value $=0.049$

Data from Table 9 show the length of parasitic infestation and employment length. The data suggest a higher percentage of parasite infestation when the length of employment was less than one year (41\%) in comparison to when the parasitic infestation was greater than one year (36\%). Furthermore, the non-parasitic infection had a greater risk in cases where employment length was more than one year. 


\section{Cureus}

\begin{tabular}{|c|c|c|c|}
\hline Years of residence & Number examined & Parasitic infestation & Non-parasitic infection \\
\hline Less than 1 year & 100 & $41(41 \%)$ & 59 (59\%) \\
\hline More than 1 year & 150 & $54(36 \%)$ & 96 (64.0\%) \\
\hline Total & 250 & $95(38.0 \%)$ & $155(62.0 \%)$ \\
\hline
\end{tabular}

\section{TABLE 9: Relationship between the infestation of intestinal parasites and employment length}

P-value $=0.425$

Table 10 illustrates infected patients in combinations with other disorders. Of the 193 patients that were infested with parasites, 72 patients were non-infected with other disorders, two patients were infected with hepatitis $\mathrm{C}$ virus (HCV), seven with human immunodeficiency virus (HIV), two with atopic dermatitis, four with abdominal pain, and eight with hepatitis B surface antigen (HBsAg).

\begin{tabular}{|c|c|c|c|c|c|c|c|}
\hline Risk Factors & $\begin{array}{l}\text { Non- } \\
\text { infected }\end{array}$ & HCV & HIV & $\begin{array}{l}\text { Allergic cutaneous (atopic } \\
\text { dermatitis) }\end{array}$ & $\begin{array}{l}\text { Abdominal } \\
\text { pain }\end{array}$ & HBsAg & Total \\
\hline Parasitic Infestation & $\begin{array}{l}72 \\
(37.3 \%)\end{array}$ & $\begin{array}{l}2 \\
(100 \%)\end{array}$ & $\begin{array}{l}7 \\
(87.5 \%)\end{array}$ & $2(50.0 \%)$ & $4(19.0 \%)$ & $\begin{array}{l}8 \\
(36.4 \%)\end{array}$ & $\begin{array}{l}95 \\
(38 \%)\end{array}$ \\
\hline $\begin{array}{l}\text { Total Number per } \\
\text { participant }\end{array}$ & 193 & 2 & 8 & 4 & 21 & 22 & 250 \\
\hline
\end{tabular}

\section{TABLE 10: Infected patients in combination with other disorders}

P-value $=0.016$

\section{Discussion}

Intestinal parasitic infestations and the associated diseases are still prominent in the tropical and sub-tropical areas of the world and are more common in developing nations. This high rate of infestation might be attributed to poor hygiene standards in developing countries. The prevalence of intestinal parasites is largely due to poor personal hygiene practices and environmental sanitation, inadequate supply of safe water, and ignorance of health-promoting practices. The prevalence of intestinal parasitic diseases is higher among expatriate workers due to poor sanitation. The current study showed that the prevalence of total intestinal parasites reached 38\%. In one of the previous studies in the district of Derna, Libya, the prevalence of infestation was found to be 31\% [11]. This prevalence rate was found to be higher as compared to the other studies in Zawia, Libya, with 10.6\% [12], and 12.88\% in Benghazi, Libya [13]. Another study conducted among school children by Ben Musa in 2007, reported a prevalence of $14.6 \%$ [14]. This prevalence is also higher than the study done in other countries, such as in Saudi Arabia, where the prevalence was 29.4\% [15], Nepal, with a prevalence of 
$18.4 \%$ [16], and Brazil, with a prevalence of $22.3 \%$ [17].

Different studies conducted in Alhag Yousif Area, Khartoum, Sudan [18] and southern Sudan [19] showed a higher prevalence of $64.4 \%$ and 66\%, respectively. The present study showed that intestinal protozoan parasitic infestations were more prevalent than helminthic infestations, in corroboration with the previous studies [20-23]. The present study revealed that the highest proportion of parasitic infestation was in age groups ranging above 45 years [21,23]. Furthermore, the present study found that there is no statistical significance $(\mathrm{P}=0.581)$ between age groups and the rate of infestation. Our data agrees with the findings of Okyay P et al., 2004 [24], Sadaga, 2007 [11], and Chandrashekhar et al., 2005 [25]. In this study, the prevalence of an intestinal parasitic infestation of expatriate workers in males was higher than in females. The percentage was $42.5 \%$ and $20 \%$ in females and males, respectively [24-25].

\section{Conclusions}

The prevalence of parasitic infestation was relatively high (38\%) and was affected by individual hygiene. Therefore, comprehensive healthcare education aimed at reducing parasitic infestation is needed. Social awareness through media and other avenues provides an appropriate gateway for ensuring all individuals, including expatriate workers, are educated. It is recommended that all expatriate workers should be checked and treated, if necessary, upon arrival to Libya. The combination of adequate hygiene practices and preventative measures in expatriate workers could enable a decrease in the prevalence of parasitic infestations.

\section{Additional Information \\ Disclosures}

Human subjects: Consent was obtained by all participants in this study. Ethical Board of Benghazi Medical Center issued approval 136319. Animal subjects: All authors have confirmed that this study did not involve animal subjects or tissue. Conflicts of interest: In compliance with the ICMJE uniform disclosure form, all authors declare the following: Payment/services info: All authors have declared that no financial support was received from any organization for the submitted work. Financial relationships: All authors have declared that they have no financial relationships at present or within the previous three years with any organizations that might have an interest in the submitted work. Other relationships: All authors have declared that there are no other relationships or activities that could appear to have influenced the submitted work.

\section{Acknowledgements}

The authors would like to acknowledge the Anti-Illegal Immigration Agency of the Ministry of the Interior, Benghazi, Libya, for allowing us to conduct the research on immigrants, and the medical laboratory department of the High Institute of Benghazi, for allowing us to use laboratory facilities and most consumable materials for free. The authors would like to extend their thanks to all patients who participated in this study.

\section{References}

1. Solomons NW: Pathways to the impairment of human nutritional status by gastrointestinal pathogen. Parasitology. 1993, 107:S19-S35. 10.1017/S003118200007548X

2. Albonico M, Crompton DW, Savioli L: Control strategies for human intestinal nematode infections. Adv Parasitol. 1999, 42:277-341. 10.1016/S0065-308X(08)60151-7

3. Utzinger J, N'Goran EK, Marti HP, Tanner M, Lengeler C: Intestinal amoebiasis, giardiasis and geohelminthiases: their association with other intestinal parasites and reported intestinal symptoms. Trans R Soc Trop Med Hyg. 1999, 93:137-141. 10.1016/S0035-9203(99)90287-0 
4. Nolla AC, Cantos GA.: Relationship between intestinal parasites in food handlers and epidemiological factors in the city of Florianópolis, Santa Catarina, Brazil [Article in Portuguese]. Cad Saude Publica. 2005, 21:641-645.

5. WHO Expert Committee: Prevention and control of schistosomiasis and soil-transmitted helminthiasis. World Health Organ Tech Rep Ser. 2002, 1-57.

6. Nematian J, Nematian E, Gholamrezanezhad A, Asgari AA: Prevalence of intestinal parasitic infections and their relation with socio-economic factors and hygienic habits in Tehran primary school students. Acta Trop. 2004, 92:179-186. 10.1016/j.actatropica.2004.06.010

7. Quihui L, Valencia ME, Crompton DW, Phillips S, Hagan P, Morales G, Díaz-Camacho SP: Role of the employment status and education of mothers in the prevalence of intestinal parasitic infections in Mexican rural schoolchildren. BMC Public Health. 2006, 6:225. 10.1186/14712458-6-225

8. Kang G, Mathew MS, Rajan DP, Daniel JD, Mathan MM, Mathan VI, Muliyil JP: Prevalence of intestinal parasites in rural Southern Indians. Trop Med Int Health. 1998, 3:70-75. 10.1046/j.1365-3156.1998.00175.x

9. Ash LR, Orihel TC: Parasites: a guide to laboratory procedures and identification . Parasitol Today. American Society of Clinical Pathologists Press, Chicago; 1988. 4:62. 10.1016/01694758(88)90073-7

10. Whitley E, Ball J: Statistics review 4: sample size calculations . Crit Care. 2002, 6:335. 10.1186/cc1521

11. Sadaga GA, Kassem HH: Prevalence of intestinal parasites among primary schoolchildren in Derna District, Libya. J Egypt Soc Parasitol. 2007, 37:205-214.

12. Elsaid MMA, Shaktur AT, Elsaid SM, EL-Alem MDEE, Traish KO, Kahbar F: Prevalence of intestinal protozoa in primary schools in Zawia City, Libya. Nat Sci. 2014, 12:67-71.

13. El-Ammari NE, Nair GA: Critical evaluation of the intestinal protozoan parasites among Libyan and other African residents of Al-Khoms, Libya. J Entomol Zool Stud. 2015, 3:42-46.

14. Ben Musa N, Sehari A, Hawas A: Intestinal parasitic infections among school children in Tripoli, Libya. J Egypt Soc Parasitol. 2007, 37:1011-1016.

15. Asfaw ST, Goitom L: Malnutrition and enteric parasitoses among under-five children in Aynalem Village, Tigray. Ethiop J Health Dev. 2000, 14:67-75. 10.4314/ejhd.v14i1.9931

16. Yong TS, Sim S, Lee J, Ohrr H, Kim MH, Kim H: A small-scale survey on the status of intestinal parasite infections in rural villages in Nepal. Korean J Parasitol. 2000, 38:275-277. 10.3347/kjp.2000.38.4.275

17. Molan AL, Farag AM: Prevalence of intestinal parasites in school children of Arbil, northern Iraq. Saudi Med J. 1989, 10:107-110.

18. Siddig HS, Mohammed IA, Mohammed MN, Bashir AM: Prevalence of Intestinal Parasites among selected group of primary school children in Alhag Yousif Area, Khartoum, Sudan. Int J Med Res Health Sci. 2017, 6:125-131.

19. Magambo JK, Zeyhle E, Wachira TM: Prevalence of intestinal parasites among children in southern Sudan. East Afr Med J. 1998, 75:288-290.

20. Lindo JF, Dubon JM, Ager AL, et al.: Intestinal parasitic infections in human immunodeficiency virus (HIV)-positive and HIV-negative individuals in San Pedro Sula, Honduras. Am J Trop Med Hyg. 1998, 58:431-435. 10.4269/ajtmh.1998.58.431

21. Pinlaor S, Mootsikapun P, Pinlaor P, Pipitgool V, Tuangnadee R: Detection of opportunistic and non-opportunistic intestinal parasites and liver flukes in HIV-positive and HIV-negative subjects. Southeast Asian J Trop Med Public Health. 2005, 36:841-845.

22. Gatei W, Barrett D, Lindo JF, Eldemire-Shearer D, Cama V, Xiao L: Unique cryptosporidium population in HIV-infected persons, Jamaica. Emerg Infect Dis. 2008, 14:841-843. 10.3201/eid1405.071277

23. Asma I, Johari S, Sim BL, Lim YA: How common is intestinal parasitism in HIV-infected patients in Malaysia?. Trop Biomed. 2011, 28:400-410.

24. Okyay P, Ertug S, Gultekin B, Onen O, Beser E: Intestinal parasites prevalence and related factors in school children, a western city sample-Turkey. BMC Public Health. 2004, 4:64. 10.1186/1471-2458-4-64

25. Chandrashekhar TS, Joshi HS, Gurung M, Subba SH, Rana MS, Shivananda PG: Prevalence and distribution of intestinal parasitic infestations among school children in Kaski District, Western Nepal. J Med Biomed Res. 2005, 4:78-82. 10.4314/jmbr.v4i1.10672 